\title{
洗毛用溶 剂についで*
}

最適溶剂探求のための一考察

会員佐 貫 治 夫

\section{1.まえがき}

羊毛紡績（梳毛およひ紡毛）における最初の処理段階 としての珗, 乾毛工程の役割はきわめて大きく，その処 理結果の巧拙によってカーンンク以後の後続諸工程に対 して大きな影響を及ぽし，ひいては紡績糸や織物なとの 諸製品の品質を左右することになる。

近時紡績諸分野の工学的研究の進展に伴い，羊毛紡績 においてもカーノンク以後の諸工程においては急速な技 術的革新か行なわれ, 高能率化, 高品質化, 低コスト化 を意凶した連涜自動方式に基つぐ生産機構の導入か実現 しつつある.これに対してこのような重要な役割を持つ 侁, 乾毛工程のみは, 新しい先剤の採用や一部の单位機 械の機構上の部分的改善か行なわれた以外には，全体と しては旧態依然とした長大な設備てあって，数槽を連結 してその中に満たされている夜中に原毛を骎せきして順 次前進移行させて珗い上けるという方式て，能率的にも 决して十分とはいえないようてある。（現在一般に行な われている珗毛方式としては，せっけんソータ痹による アルカリ珗毛や非イオン系珗浏なとによる中性洗毛ある いはこれらの併用方式か行なわれて和り，いすれもとの 第 1 槽ては温水のみによる侵毛処理すなわち広義のスイ ントスカーリンクを採用する場合か多い).

最近になってこのよらな害情に対して根本的な再検討 か要望されより簡易て完全な新方式の出現を期待する 気連か高まってきている，そしてこれを実現するための 行き方の一つとして，溶剂洗毛方式か住目され関心か持 たれている.（またこく最近ノェノトスカーリンク方 式かクロースアノプされてきたか，これはまた試験段 階てあり，本格的な実用化には至っていない)。 わか国

r Studies on Solvents for Degreasıng Raw Wool

N H Sanukı Member, 東京農工大学工学部
における溶剤侁毛の歴史はかなり古いもののようてある か, 過去のものは固定密閉式てあり, 操作上非能率, 不 便てあったのと，使用焀剤による火災就よひ衛生上の危 険なとから,タール付羊毛やノイルなどの特殊原料の場 合に一部使用された以外にはあまり発展普及しなかっ たしかし戦後国内ても不然性容刘の製造かさかんとな り, また石伷系溶剤の進出子みられ, 本方式の有効性か 再認識され，わか国ても数年前某社てパイロ，トプラ ント（浸せき方式）の稼動を試み，またオーストラリア C S I R O やスエーデン, イタリヤなとに执ても新機 構に基つく連続自動方式（流下方式）を完成し，実際操 業を行なっていると伝えられている。

しかし今後わか国て本格的に本方式を採用実施するた めには，またいろいろ検討，研究を要する問題か残され ており，はたして本当に従来の普通侁毛方式より有利て ありこれに代替し得るものてあるかとうかについて は，慎重に総合的に判断する必要かあると思われる，そ こてこのために必要と考えられる種々な研究課題のら ち，ます“最適容剂の探求（容剂の選択＂について検 討する必要かあると思われる。すなわちわか国て連続方 式による溶剤侁毛を実施するとした场合，数多くある容 剤の中てとの容剂を選択使用するのか最もよいかという 点について結論を出すためてある，そしてこの場合，解 析を要する項目としては

1）ヨーク除去能（溶脱力）について

2）疲労性について

3）回収性について

4）機械材質への奮蝕性について

5 ）引火爆発性, 衛生上について

6）珗い上りの羊毛の性状，紡績性について

7）価格について

8 ）容剂と他のものとの倱合系による有効性について 
なとか挙けられこれらの各 結果を総合して判断し結論つ ける必要かあるおけてある。 ここてはますヨーク除去能, 液の疲労性なとの項目を主な 対象として行なった実験の結 果についてその概要を述へ る.

2. ヨーク除去能 (溶 脱力）について

先毛用容剂としてのもっと b重要な基本的必要条件とし ては，いうまてもなく羊毛脂 の容解性の大きいことてあ る. そしてこの傛解除去能は 容剤の種類によってかなりの 相違かあるものと考光られ る. そこて本項ては, 現在工

業的に生産されて打り入手容易な各系統の容剂から代表 的なむのをいくつか選び, それらの間にとの程度の差か あるかについて比較検討してみた。この場合試料として は，ます脱水ラノリンを用いた場合を行ない，つきに実 際のグリーシ ウールを使用して測定解析した。

\section{1 ラノリンを圾料とする場合の基礎的解析}

実際の原毛 (クリージウール)を試料として使用する まえに, もっとも基礎的な解析として脱水ラノリンを試 林として側定を行なった。すなわちクリーシウールを 用いた場合には，容剤て処理することによって，可容性 クリース分の溶解とともに不容性スイント分も一部物理 的に分離脱落分散してくるのて，グリース分のみを対象 とした㒈密な意味ての容脱力の測定はてきない，そこて ますここてはラノリンを試料として測定することとし た。

\section{a 基本的容解量曲線の側定比較}

実際処理において対象となると考兄られる処理時間の 範囲内に括いて，ラノリンに対する容解量か容剂の種類 によってとの程度相違するかを知るために，各溶剤の場 合の基本的容解量曲線を求め比較してみた。

実験方法は省略するか，採用した各溶剂の諸性質を第 1表にまとめて示す。い寸れも現在わ加国て生産されて

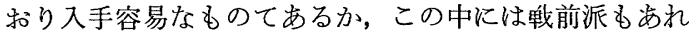
は戦後新しく登場したものもあり，また引火爆発性，有
（第1表）採 用 溶 凨一覽 表

\begin{tabular}{|c|c|c|c|}
\hline 名 & 化 学 式 & 比重 & 坲点 \\
\hline ト V & $\mathrm{CH}_{3} \cdot \mathrm{CO} \cdot \mathrm{CH}_{3}$ & 0.791 & $565^{\circ} \mathrm{C}$ \\
\hline ールケトン & $\mathrm{CH}_{3} \cdot \mathrm{CO} \cdot \mathrm{C}_{2} \mathrm{H}_{5}$ & 0.805 & 796 \\
\hline キサノン) & $\mathrm{C}_{6} \mathrm{H}_{10} \mathrm{O}$ & $09<8$ & $147 \sim 156$ \\
\hline 一テル & $\mathrm{C}_{2} \mathrm{H}_{5} \mathrm{OC}_{2} \mathrm{H}_{5}$ & 0.708 & 34.6 \\
\hline ターペン & 一 & 0.794 & $187 \sim 208$ \\
\hline シ 油) & - & $0.770 \sim 0.800$ & $\sim 200 \sim$ \\
\hline - ル & $\mathrm{C}_{6} \mathrm{H}_{6}$ & 0.879 & 80.1 \\
\hline$\stackrel{-}{-}()^{2}$ & $\mathrm{C}_{6} \mathrm{H}_{5} \mathrm{CH}_{3}$ & 0.872 & 110.5 \\
\hline ルエチレン & $\mathrm{CCl}_{2}: \mathrm{CHCl}$ & 1.464 & $\sim 87 \sim$ \\
\hline ルエチレン & $\mathrm{CCl}_{2}: \mathrm{CCl}_{2}$ & 1.630 & $\sim 120 \sim$ \\
\hline ロライド & $\mathrm{CH}_{2} \mathrm{Cl}_{2}$ & 1.336 & 39.8 \\
\hline 炭 素 & $\mathrm{CCl}_{4}$ & 1595 & 768 \\
\hline $\begin{array}{c}\text { ゼ } \\
\text { ロ }\end{array}$ & $\mathrm{CCl}_{3} \mathrm{CH}_{3}$ & 1.570 & 458 \\
\hline ジクロライド & $\mathrm{CH}_{2} \mathrm{Cl} \cdot \mathrm{CHCl} \cdot \mathrm{CH}_{3}$ & 1160 & $94 \sim$ \\
\hline
\end{tabular}

毒性，価格なとの点からして先毛用として実際工場て使 用するには不適当てあることか初めからわかっているも のもあるか，ここてはもっとも基礎的な解析てあるのて これらのものも含め, 各系統から代表的な溶剂をいくつ か選ひ，それらの容脱力を比較することとした．

得られた結果として，容剂別に容解量曲線を园示した ものか第1困てある，本四によって明らかなように，同

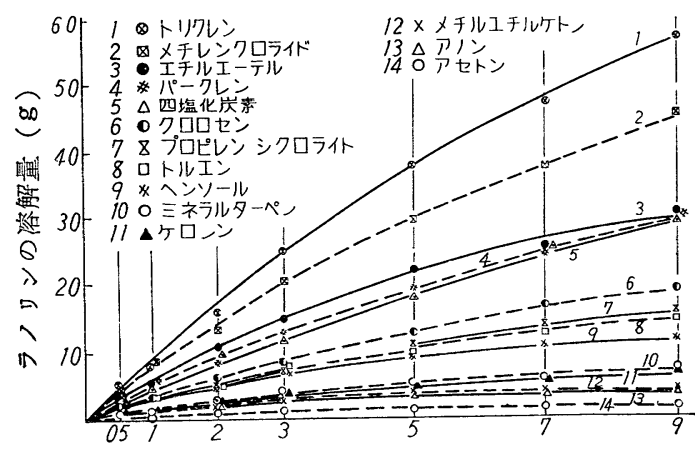

処理時間 (min)

（第1区）各溶剤による脱水ラノリンの溶解量曲線

一実験条件によった場合脱水ラノリンに対する溶解力は 容剤の種類によって非常に相違する，短時間処理て相当 の容解力を示すものは以後も処理時間の経過とともにか なり急敫に容解量を増大するか，処理初期に低値のもの は 5 min〜継続処理しても容解量はほとんと変化なく一 
定低值を示す．そして最大の溶解力を示すトリクレンの 場合と最小のアセトンの場合とては, その容解力は実に

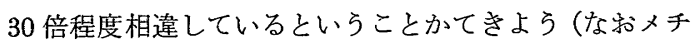
ルェチルケトンによるラノリンの溶解状態はきわめて特 異てあって, 本測定結果は完全容解量とはいいにくく, このような現象から判断して M E K. は洗毛用容郕と しては不適当と考学られる。またフノンるやや同様な傾 向か認められる)。実際処理において主な対象となり主 役を果たすと思われる合成采容剤と石伷系溶刘とては， そのラノリン容解力に非常に大きな差かあり, この点て は前者かはるかにすくれていることか指摘てきる。なお 本項の測定結果から得られたもら一つの点として, 溶剂 の比重値の関係からラノリンの容解方向か溶剤の種類に よって上方へのものと下方へのものとに分かれることて あり（脱水ラノリンの比重は 0 943），このような容解 方向すなわち液ての層別方向は，実際処理における採 用容剂の選択和よひ機械装置の設計に対して一つの要因 となるてあろう。

な跤本項の測定結果はあくまてもラノリンを試料とし た場合てあって，実際の原毛を処理した場合にはたして 同様の容脱力順位を示すかとうかは後項の測定結果にま たねはならない。クリーンウールを処理する場合には， 不容性スイント分およひ固形きょう雑物も加わりまた 処理方式によっても影響を受けることか考兄られるのて ある。

\section{b 飽和燶度の測定比較}

ラノリンを試料とする基礎的な解析に打いてもら一つ の重要な事項として則定を要するのは, 各溶剤の飽和濃 度 $\left(C_{s}\right)$ を隶めることてあるすなわち一定量の容剂に よってグリース分をとの程度まて容解し得るかといら限 界值を求めることてあり, これは最適溶剤の探求上から もまた容剂侁毛を実際に工場て実施する場合にも必要な 事項てある. そこて本項ては各溶剤の場合について測定 してみた（たたしメチルェチルケトンは前項の側定結果 からして不適当と判断されるのて除外した).

実験方法は省略するか，13 種類の溶剤について測定し た結果を第 2 冈に示す これによってわかるように基礎 的に脱水ラノリンを試料として湘定した場合， $C$ s值は 容剤の種顛によって非常に相違し, 最大のものと最小の すのとては実に 100 倍近い差かあるといえよう. そして この $C_{s}$ の順位は, 前項の容解量曲線に示された順位と 招拉むね一致して和り（部分的《は順位の入れかわって いるものも㐫るか), 初期溶解力のすくれている溶剂は,

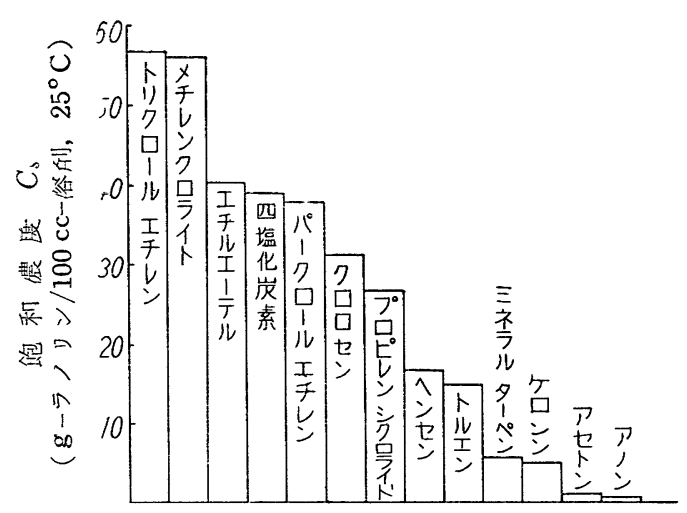

（第2区）脱水ラノリンを使用した皆合の 各溶剂の飽和温度

処理時間の担当長い範囲にわたって容解作用を継続進行 させるか, 容解力の小さい溶剤の場合には, いくら長時 間作用させてもその容解量は初めの短時間に溶解した 量とあまり変わらないことかわかる。

実際に容剂珗毛を実施する場合，採用すへ容剂としは

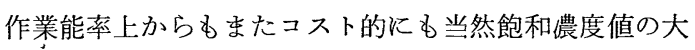
きいものか好適と考兄られるのてあるか, 本項の側定結 果によって明らかなよらに， $C_{s}$ 值は溶剂によって非常 に相違するのて, その選択には十分考慮する必要か专万 う。たたし実際の原毛を処理する場合の夜の疲労性（原 毛の残脂率という観点からした）については, 别途に側 定解析する必要かあると考兄られる。

\section{2 原毛を試料とする場合の基礎的解析}

本項ては実際の原毛 (クリーンウール)を試籵として 使用し, 各浴剂のヨーク除去能の比較を行なったこの 場合実際処理方式として浸せき方式と流下方式の $2 つ の$ 場合かあるのて，この両者についてそれぞれ解析し た、たたし実際の処理装置ては, 数セクションに分かれ て同様な操作を数回繰り返したり(繰り返し操作), あ るいは容剤液中て摇動かくはんを与えたりして処理効率 の増大を冈っており, 最終段階ての先い上り羊毛の残脂 率はきん少てある（少なくとも1\%以下）ことか必要て あるか，ここては浴㓮間の比較を主目的としているの て，ますすへて単一操作（ある量の原毛をある量の容剂 てたた 1 回たけ処理する場合）によることとし，また流 下方式の場合としては積極的な夜压を付与することは行 なわず自然液重によることとし，浸せき方式の場合とし ては摇動かくはんを付与しない静的浸せきの方法による こととしたのてある。さらにまた実際処理装置ては，い すれの方式ても必す絞りローラ装置か設置されて打 
り，これによる絞り出し作用が先毛効率すなわち洗い上 り羊毛の残脂程度に非常に大きな影響を持つことになる が,ここてはやはり浴郕の差を求めるのを主目的とす るという意味から，絞り程度をかなり甘くした場合につ いてます実施することとした。したがって前記の単一操 作によったことと複合して，処理後羊毛塊の残ヨーク率 は実際の最終先い上りの場合よりはかなり大きな範囲に ととまり，このような場合に和ける比較ということにな るわけてある。

な和試料原毛としては，わか国の毛紡工場て使用され ている原毛中てもっとも標凖的なものとして, オースト ラリア産メリノ種, 質番 64 s のものを使用し, バー, シ 一トなとの植物性きよう雑物およひ土砂のない一様なヨ 一ク付着状態を得て試料とした。本試料原毛集団のヨー ク分付着量（原毛絶乾量に対する）はつぎのようてる (母平均の $95 \%$ 信頼限界て示す).

$2528 \pm 126$ （スイント分 $7.72 \pm 036 \%$ ，クリース分 $1756 \pm 090 \%)$

また試料原毛塊の多孔度值は常に $90 \%$ の状態に規定 して測定を実施した。

a. 流下方式（無加圧単一操作）による場合 実際処理工程の連続方式容剤侁毛装置として，C S I R O のンローン紡織研究所なとて行なわれている方法 は，移動ラチス上に載せられた原毛フリースの上方から 溶郩を噴射注加し，可容性クリース分を主とするヨーク 分和よひ土砂なと固形さよう雑物の一部は下方に滴下除 去され，次段階て同様な機構によって午質スイント分を 噴射水先している。こ机はすなわち流下方式に基つくも のてあり、このような方式による利点としては，フォー クモーションかないため䋐維に無理かかからず，からみ 合い凝集化を起こすことも少なく，したかってカーシン クによる瀻維の切断か少なくト,プ歩留りかよく, 紡出 糸，織物なとの製品の品質の向上を区ることかてきると いわれている そこて本項ては，このような流下方式に よる容剂冼毛の基礎的事項として，無加圧単一操作によ った場合について測定比較してみた。

実験方法は省略するか, 初流下所要時間 $T_{f}(\mathrm{sec})$, 単 位時間当り流出量 $Q_{f}(\mathrm{cc} / \mathrm{sec})$, 抽剂比 $\alpha_{f}$, 排出ヨ-ク 量 $Y_{f}(\mathrm{~g})$, 処理後原毛塊の水に上る抽出分残留率 (残 留スイント率 ${ }_{s} R_{f}(\%)$, 処理後原毛塊のエーテルによる 抽出分残留率 (残留クリ一ス率) ${ }_{g} R_{f}(\%)$ ，処理後原毛塊 の残留ヨーク率 ${ }_{y} R_{f}(\%)$ の各項目について測定した。

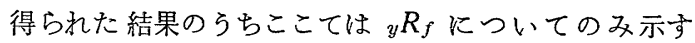

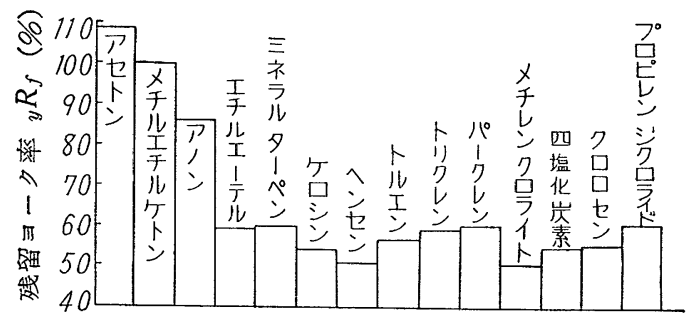

（第 3 図）流下方式による各溶剤の場合の处理後 原毛塊の残留 $ヨ$ ーク率 $\left(y R_{f}\right)$ の比較

(第 3 冈参照)。この值は ${ }_{s} R_{f}$ と ${ }_{g} R_{f}$ の 2 残留率を加 算したものてあつて，もちろんこの值の小さい溶郕が 一ク分除去能（溶脱力）のすくれたものてあることにな るそして前述したように，溶剂可溶性のグリース分の 溶出に伴って，不容性スイント分も同時に一部はメカニ カルに分離脱落分散するものと考它られるから，前者の 2 残留率はそれほと嚴密な区別は持たないことになり， この両者を加算した本残留率の值の大小か，流下方式に よった場合の浴剤の種類による珗毛効率を比較し判断 する上において重要な意味を持つことになるわけてあ る.

本結果によって考察すると、ベンセンとメチレンク ロライトの両者かもっとも容脱力かすくれて和り，つき に〔ケロシン, 四塩化炭素, クロロセン, トルエン]の 一群か同程度てあり，そのつきには〔エチルェーテル， トリクレン, ミネラルターペン, パークレン, プロピレ ンンクロライト」の一群か同程度てあり, 以下アノン, メチルエチルケトン，アセトンとかなりの差を示して容 脱力は劣っている. このうちプロピレンシクロライド は排出ヨーク量 $Y_{f}$ 值か大きいにもかかわらず，残留ヨ 一ク分かあまり小さくない結果を示したか，これはョー ク中の可溶性グリース分の排出は多いか，不容性スイン 卜分の残留もまた多いために ${ }_{y} R_{f}$ 值かやや大きくなっ たものと解釈される，逆にヘンン゙ールの場合は残留スイ ント量か極端に少ないといらことによって ${ }_{y} R_{f}$ 值か小 さく順位か上かっているか, 残留グリース量はかなり多 いのてある。な和これらとともに考えられることは，比 重の軽い容剂のうちベンソール, ケロシン, トルェンの ように $\alpha_{f}$ 值の小さいものは，それたけ処理後差毛塊中 の滞留液量か多いわけてあるか, 試料塊をカラス管容器 から取り出したのち絞り作用を与えるのて, 同一程度に 校られても饺り出され除去される液量は多いのて，この 液とともにその中に浴解されていたかなり檂厚なヨーク 分か排除される割合も多くなり，したかってそれたけ残 
留ヨーク率は小となることになる。このことがれらの 容凬の場合 ${ }_{y} R_{f}$ 值の小さくなった理由と考えられるが 実際処理上からいっても必ず先毛装置中に絞り処理段階 を設けねばならぬわけてあるから， $\alpha_{f}$ 值か小て絞り出 される量が多いほうか適切てあるといらことになること む考觉られよう。しかし全般的に検討してみると、ケト ン類系の 3 溶剤は非常に悪い結果を示しているか，他の 各容㨈間にはそれはと大きなヨーク分残留量の相違はな いものと判断するのか妥当なようてある。たたしこれは 絶乾量 $5.0 \mathrm{~g}$ の原毛に対して $100 \mathrm{cc}$ の容剂を住加流出 させた場合についててあるか，本結果によっても流下方 式といら処理機構の特殊性がなにか存在するように推察 されるのてある，たとえは浴剮の純粋な浴脱力以外にメ カニカルなヨーク分除去能か加味されるために容剂間の 差か少なくなるのてはないかということてあって，この 点については次項の浸せき方式の場合の側定結果と比較 すれは明らかとなるものと思われる

ここて本項のまとめとして，傛剤別飞総合的な順位つ けをするために，各側定項目において得られた順位によ って各溶剂を採点し（最高点14点〜最低点 1 点として, $T_{f}$ についてはこの値の小さいものから順に, $Q_{f}, \alpha_{f}$ 实よひ $Y_{f}$ につてはこの值の大きいるのから順に，ま た $R_{f},{ }_{c} R_{f}$ 抽よひ ${ }_{3} R_{f}$ についてはこの值の小さいも のから順に大きな得点を与充た。たたし同一順位あるい は同一程度と判断される場合には，それらの容剂に対し てすへて同一得点を与えた)。それらを加算してみると 第 2 表のような結果となるこの総合得点によって順位 つけると，流下方式による場合の容脱力のみを対象とし
た好適容剂としてはつきの順序となる。

メチレンクロライド〉トリクレン〉四塩化炭素〉ェチ ルエーテル>パークレン>プロピレンジクロライド> クロロセン>トルェソ>ケロシン>ヘンゾール〉ミネ ラルターペン >アセトン>メチルエチルケトン > アノン

これによってわかるように，合成系溶剤 6 種類がすべ て上位に続いており，石油系溶霅はいすれも中位以下て ある。このような順位となる理由の一つとして, 合成系 容剤の比重値か大きいことによって $\alpha_{f}, Y_{f}$ ての得点 か大きいことか挙けられるか，処理方式として流下方式 による場合は，事実この容剤の重さといらことが処理機 構に直接大きな影響を及注すと考えられるから，総合的 容脱力のみについての順位としてはこれてよいと考えら れる（たたし経済的面からすると，比重の大きい溶剤は 同一重量ても夜量は少ないるけて，その単位洒格とにら み合わせてコスト的には別途に考慮を必要とするれけて ある)

b 浸せき方式（静的単一操作）による場合 実際の連続容剤洗毛処理方式として, 前項の流下方式 そは別に,わか国の某工場て試みられたものは, 洗槽中に 満された溶剂中を中板 (多数の孔をあけてある)上に供給 した原毛を，爪車によって浸せき前進移行させ，クリ一 ス分を溶解除去も同時に土秒なとのきよう雑物を排除す るといらものてある. そこてここても基礎的事項として このような浸せき方式の場合（たたし単一操作）につい ても湘定解析する必要かあると考兄られるのてある。

実験方法は省略するか，抽剂比 $\alpha$, 排出 $\exists$ ク量

（第 2 表） 流下方式による場合の溶脱力のみについての各溶剤の総合得点と順位

\begin{tabular}{|c|c|c|c|c|c|c|c|c|c|}
\hline 溶㶡名測定項目 & $T_{f}$ & $Q_{f}$ & $\alpha_{f}$ & $Y_{f}$ & ${ }_{\varepsilon} R_{f}$ & ${ }_{\mathrm{s}} R_{f}$ & ${ }_{y} R_{f}$ & 合計点 & 順 位 \\
\hline セ $\quad$ 年 & 13 & 12 & 7 & 1 & 1 & 1 & 1 & 360 & 12 \\
\hline メチルェチルケトン & 105 & 95 & 55 & 2 & 2 & 2 & 2 & 335 & 13 \\
\hline $\boldsymbol{P}$ & 1 & 1 & 3 & 3 & 3 & 12 & 3 & 260 & 14 \\
\hline エチルエーテル & 13 & 12 & 8 & 4. 5 & 5 & 12 & 6 & 605 & 4 \\
\hline 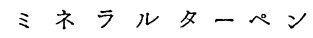 & 3 & 3 & 55 & 12 & 75 & 4.5 & 6 & 41.5 & 11 \\
\hline ケ म & 2 & 2 & 3 & 13 & 11 & 8 & 105 & 495 & 9 \\
\hline ベ ン ゾール & 4 & 6 & 1 & 45 & 14 & 4. 5 & 135 & 475 & 10 \\
\hline$F \quad ル \quad x \quad y$ & 65 & 6 & 3 & 6 & 75 & 12 & 105 & 515 & 8 \\
\hline $\begin{array}{lllll}ト & y & \eta & v & \nu\end{array}$ & 105 & 12 & 13 & 105 & 75 & 12 & 6 & 715 & 2 \\
\hline パ $\quad-\quad \eta \quad v \quad$ V & 9 & 95 & 14 & 8 & 75 & 4. 5 & 6 & 585 & 5 \\
\hline メチレンクロライド & 13 & 14 & 105 & 8 & 13 & 8 & 135 & 800 & 1 \\
\hline 四 塩 化 炭 素 & 65 & 6 & 12 & 105 & 11 & 8 & 105 & 645 & 3 \\
\hline ク म & 65 & 6 & 105 & 8 & 11 & 4. 5 & 105 & 570 & 7 \\
\hline プロピレンジクロライド & 65 & 6 & 9 & 14 & 4 & 12 & 6 & 575 & 6 \\
\hline
\end{tabular}


$Y_{s}(\mathrm{~g})$, 処理後原毛塊の水による抽出分残留率（残留ス イント率） ${ }_{s} R_{s}(\%)$, 処理後原毛塊のエーテルによる抽 出分残留率（残留クリース率） ${ }_{g} R_{s}(\%)$, 処理後原毛塊 の残留ヨーク率 ${ }_{y} R_{s}(\%)$ の各項目について測定した。 得られた結果のうちここては ${ }_{y} R_{s}$ についてのみ示す（第 4. 凶参照)。この值は ${ }_{s} R_{s}$ と ${ }_{g} R_{s}$ の 2 残留率を加算し たものてあって，もちろんこの値か小さい力かよい 焀

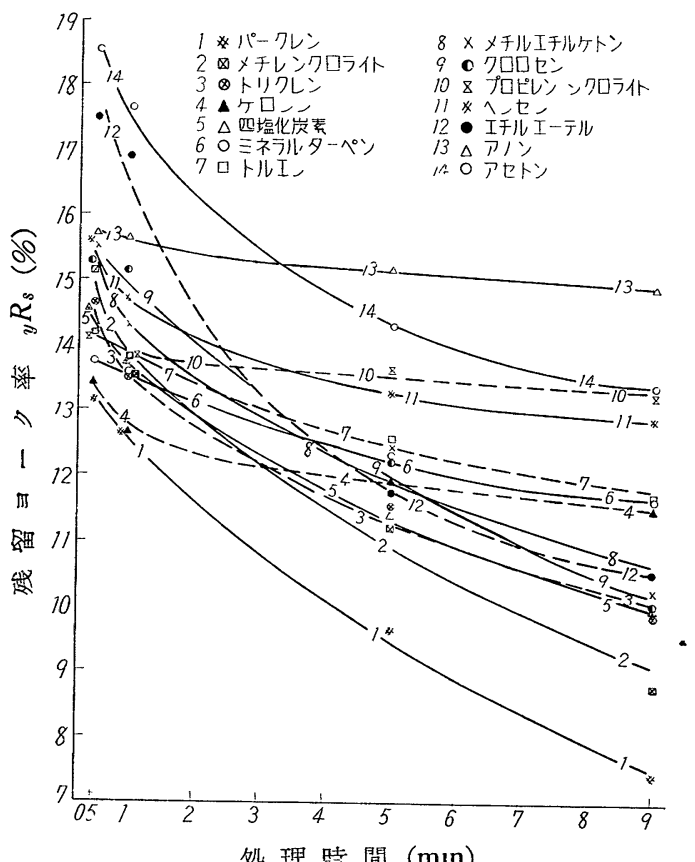

（第 4図）骎せき方式による各浴剂の場合の处理後 原毛塊の残留ヨーク率 $\left({ }_{3} R_{s}\right)$ の比較

剂別に検討してみると，処理時間か長くなると急激に ${ }_{y} R_{s}$ 值の小となるものと, 処理時間か短くても長くても ほとんと変化しないものと 2 系絽に分かれている。 たと えはエーテルの場合は短時間処理（0 5, $10 \mathrm{~min})$ ては きわめて 俗脱力は悪いか, 長時間処理（50 min〜） と なると ${ }_{y} R$ ，值はかなり小となり相当の容脱力を示すよ うになる。各処理時間に拈ける ${ }_{y} R$, 值の合計值の小な るものから各溶剤を順位つけてみるとつきのようにな る.

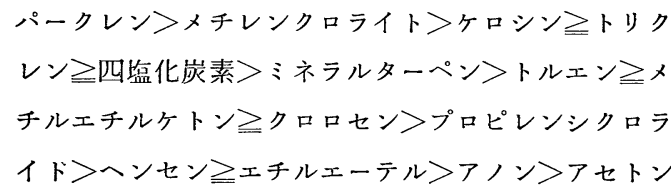

本結果によって考察すると, パークレンとメチレン クロライトの両者かもっとも容脱力かすぐれており,つ きに〔ケロシン,トリクレン, 四塩化炭素]の一群が同
程度てあり，そのつきにはミネラルターペンか入り， つきに[トルエン, メチルエチルケトン, クロロセン] の一群か同程度てあり,つきにプロピレンンクロライト か入り, 続いて〔ベンセン，エチルニーテル〕が同程度 てあり, 以下アノン，アセトンはかなりの差を示して容 脱力は劣っている，特に注目すへさことは，石伷系のケ ロンン, ミネラルターペンの両者てあって, これらは抽 剂比 $\alpha_{s}$ か極端に小さかったために採取容液量か少な く, したかって排出ヨーク量 $Y$ っ極端に少なかったの てあるか，残留ヨーク率のほらからみると，これらの容 脱力はそれほと恶くなくむしろ上位にあることてある。 この理由として考えられることは, 前項（流下方式）て も述へたように, 金絧容器中から取り出された処理後試 料塊は軽い絞り作用を与えられるのて, 北重か軽く $\alpha_{s}$ か小て滞留液量の多いこれらの容剂の場合, 同一程度に 絞られても絞り出され除去される液量か多いのて，この 液とともにその中に浴解されていたかなり檂厚なヨーク 分か排除される割合も多くなり，したかってそれたけ残 留ヨーク率は小となることになる，このことかこれらの 容剤の場合 ${ }_{y} R_{s}$ 值のかなり小さくなった理由と考えら れるか, 実際面て浸せき方式て行なら場合ても必す絞り 装置を必要とするおけてあるから，容脱力としてはその 容剤の持つ純粋な溶解力のほかに, 当然この絞り出し作 用もあわせ考皇ねはならないおけて，結局は絞り作用を 受けたあとの羊毛塊に残留しているヨーク分が少ないこ とか望ましいことになる。

ここて本項のまとめとして，容剂別に総合的な順位づ けをするために，前項（流下方式）の場合と同様に，各 測定項目において得られた順位によって各浴剂を採点し （やはり最高点 14 点〜最低点 1 点として， $\alpha_{s}$ およひ $Y_{s}$ にいてはこの值の大きいものから順に, また ${ }_{s} R_{3}$, ${ }_{5} R_{s}$ およひ ${ }_{y} R_{3}$ についてはこの值の小さいものから順 に大きな得点を与えた。たたし同一順位あるいは同一程 度と判断される場合には，それらの容剂に対してすへて 同一得点を与えた)。それらを加算してみると第 3 表の ような結果となる。この総合得点によって順位つける 之, 流下方式の場合と同様に炭化水素の塩素化合物系 (合成系)の 6 容剤かすへて上位に続いており，石伷系溶 剂は中位以下てある。たたし処理方式として浸せさ方式 による場合には，容脱力のみに対しては容剤の此重値は それほと大きな意味はなく，直接の影響を持たないと考 えられるのて, $\alpha_{s}, Y_{s}$ による得点を除外し, ${ }_{s} R_{s}$ と ${ }_{q} R_{s}$ との合計すなわち ${ }_{2} R_{S}$ 値の大小のみによって順位つけ 


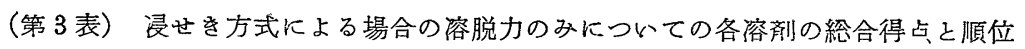

\begin{tabular}{|c|c|c|c|c|c|c|c|c|}
\hline 溶 刘名 則定項目 & $\alpha_{s}$ & $Y_{s}$ & ${ }_{s} R_{s}$ & ${ }_{s} R_{s}$ & ${ }_{y} R_{s}$ & 合計 点 & 総合順位 & $\begin{array}{c}R_{s} \text { のみネに } \\
\text { よる順位 } \\
\end{array}$ \\
\hline ע & 65 & 70 & 10 & 30 & 10 & 185 & 12 & 14 \\
\hline メチルェチルケトン & 5.0 & 80 & 20 & 130 & 70 & 350 & 7 & 8 \\
\hline ア ノ & 65 & 25 & 30 & 10 & 20 & 150 & 14 & 13 \\
\hline エチルェーテル & 80 & 12.5 & 4.0 & 50 & 35 & 330 & 10 & 12 \\
\hline ミネラルターペン & 20 & 4. 0 & 110 & 70 & 90 & 330 & 10 & 6 \\
\hline ケ $\quad$ म & 10 & 10 & 110 & 100 & 110 & 340 & 9 & 3 \\
\hline ベ ン & 30 & 25 & 65 & 30 & 35 & 185 & 12 & 11 \\
\hline ト ル $x$ & 40 & 55 & 110 & 70 & 70 & 34. 5 & 8 & 7 \\
\hline$ト \quad \mathfrak{y} レ$ & 125 & 105 & 11.0 & 100 & 11.0 & 550 & 3 & 4 \\
\hline パーク レ ン & 125 & 140 & 110 & 140 & 140 & 655 & 1 & 1 \\
\hline メチレンクロライド & 125 & 125 & 65 & 120 & 130 & 565 & 2 & 2 \\
\hline 四塩 化 岸 & 125 & 105 & 65 & 100 & 110 & 505 & 4 & 5 \\
\hline ク ロ & 95 & 90 & 65 & 70 & 70 & 390 & 5 & 9 \\
\hline プロピレンンクロライド & 95 & 55 & 140 & 30 & 50 & 370 & 6 & 10 \\
\hline
\end{tabular}

をしたほうか容脱力の比較としてはこの場合妥当てあと 考えられる.すなわちこれは前記の ${ }_{y} R_{s}$ 項のところて 示した順位てあって，これによるならば石伷系溶戍もか なりの上位にあり，また合成系容剂の中てはクロロセ ン, プロピレンンクロライドの両者かあまりよくないこ とが指摘される。

以上の結果からいえることは，繰り返し述へたよう に，実際処理においては必す絞りローラ装置があって， これによる羊毛塊中滞留容夜の絞り出し作用か行なわれ るわけてあるのて，容剤のグリース分溶解力かそれほど すくれていなくても, 比重か軽く滞留液量の多い場合に は, 絞り処理後の羊毛塊中残留ヨーク率は容解力のすぐ れた溶剂の場合とそれほと相違しないのてはないかと判 断されることてある。このような観点からすれは, 石油 系のケロシンはかなり有望ということになろう。

c. 単一操作による場合の両方式の有效性比較 a 新よひ b 両項に和いて，それぞれ流下方式と浸せ き方式によって, 同一量のクリーシウールを同一量の 各溶剤てたた 1 回たけ処理したか, 本項てはこれらの湘 定結果から，容脱力のみを対象とした場合，実際処理方 式としてはとちらかすくれているかを検討考察した。

判定の基隼としては，溶剂の溶脱力を直接示している と考只られる試料羊毛塊の処理後残留ヨーク率 ${ }_{y} R_{f}$ or $s$ 值 $\left({ }_{s} R_{f}\right.$ or $s$ 值と $R_{f}$ or $s$ 值との合計值) とよることか あっとも妥当てあると考兄られるのて, これによって比 較することとした。たたし両方式て処理時間（浴剂作用 時間）の取り扱いか異なっているのて, ${ }_{y} R_{f}$ 值はそのま まとし, ${ }_{y} R_{s}$ 值は 4, 処理時間に和ける各値の平均值によ ることとした。なおどちらの方式による場合にも本測定
結果は実際の連続処理工程として考学ると, 羊毛塊か 1 セクシュンて 1 回たけ先毛処理を受け，続いて絞りロー ラによって絞り作用を受けて送り出された位置に拈ける 状態を近似的に表現していることになるのて（たたし本 実験ての絞り程度は実際の場合よりもかなり甘いるのて あるが，ここてもこのような意味に和いての比較とい らことになる。

各方式の場合について各容剂ごとにまとめて示すと第 4表のようてある，本表によって明らかなように，同一

（第 4 表） 处理後原毛塊の残留ヨーク率 ${ }_{y} R_{f}$ or $s$ による両处理方式の有効性の比較結果

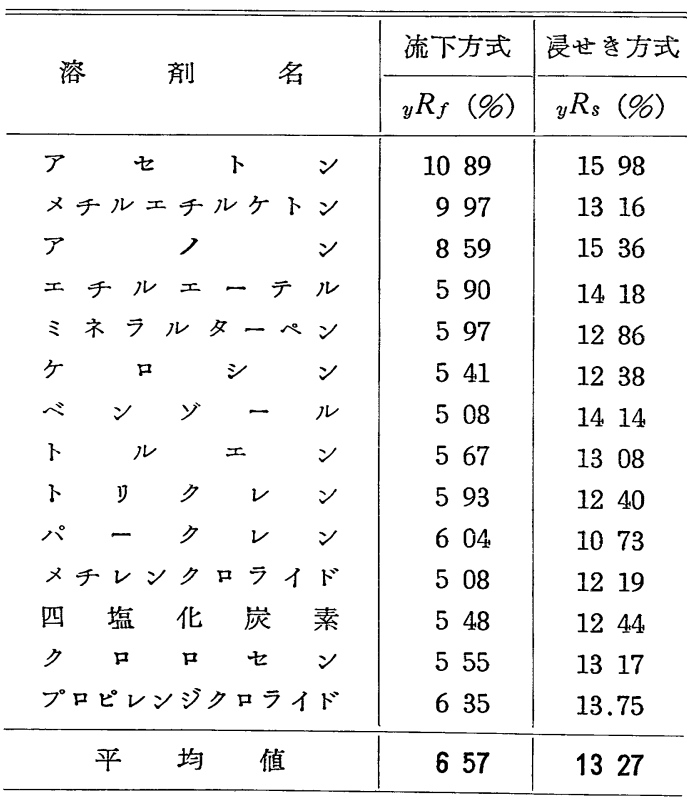

注） ${ }_{y} R_{s}$ 值は各处理時間での值の 平均值による 
量の原毛を同一量の溶沜で処理した場合すすべての溶剂 について流下方式のほうが残留ヨーク率が少なくすぐれ ているといえよう．全溶㓮についての平均值で比較して みると，浸せき方式の ${ }_{y} R_{s}=13.27 \%$ に対し流下方式の ${ }_{y} R_{f}=6.57 \%$ あ゙り，全体的には流下方式の場合の残留 ヨーク率は半分以下であることがわかる。これは a 項で も述べたように，流下方式という処理機構の特殊性が存 在し，溶剤の純粋な溶解力以外飞，原毛たい積層の上方 から下方に向からメカニカルなヨーク分除去能（押し出 乙作用）が加味されるためにもたらされる効果であると 推察される，実際処理に打いて流下方式を採用方る場合 には，ジェットスプレでかなりの液圧を与えて溶制を 原毛層上に噴射注加するわけであるから，このような現 象はより一層発現付加されるものと考兄られる（もっと も浸せき方式でも液中で摇動挸挥を与えれば，処理効率 はかなり向上すると思われるが).

つぎに各溶剤ごとに検討してみると，どちらの処理方 式にも好適な溶剂もあれば,どちらにも不適格な溶剂も 認められ，さらにまた一方の方式には好適でも他方の方 式にはあまりよくないという溶剤も存在している。溶剤 別に示してみると

アセトン……劣等グループの代表であり，両方式の場 合とももっとも成績悪く, 溶脱力は極度に劣り残 ヨーク率が非常に多くなる

メチルェチルケトン……劣等グループ中に属する．た だ浸せき方式の場合やや良い傾向を示した

アノン……少等 グループ中でもアセトンに次いで悪 く，両方式の場合とも不適当である

エチルェーテル……流下方式の場合には中程度である が，浸せき方式の場合にはかなり悪く, 全体とし てはやはり劣等グループに属する

ミネラルターペン……雨方式の場合とも大体同じ程度

で中位グループに属する

ケロシソ……耐方式の場合とも予想外飞高順位を示 し, 絞り処理後の残留ヨーク率は少なく, 優秀グ ループに入った。 これは特に不溶性スイント分の 除去能が大きいことが原因している，実用上に揖 いて注目すべき溶剤と考兄られる ベンゾール……総合的には中位グループに属するが,

処理方式によって順位は非常に相違し優劣がはっ きりしている。すなわら浸せき方式では不良であ るが，流下方式では最良結果を示した。これも不 溶性スイント分の除去能が大きかったためである
トルェン……典型的な中位グループである，両方式の

場合ともほとんど同程度の順位である

トリクレン……中位グループの上に属する。しかし浸 せき方式の場合にはかなりすぐれた結果を示す ペークレン……総合的には一応優秀グループに入る

が，処理方式によって適応性がかなり異なる。す なわち流下方式ではあまりよくないが，浸せき方 式では最良結果を示した

メチレンクロライド……優秀グループ中の最高であ り，両方式の場合とも非常に寸ぐれている．可溶 性グリース分に対する溶解力とともに，不溶性ス イント分の除去能も同時に大きいことが指摘され る

四塩化炭素……優秀グループに属する。また両方式の 場合とも同程度の効果が認められる クロロセン……中位グループに属するが流下方式の場 合の方が順位は良い

プロピレン ジクロライド……予想外に悪い結果を示 し，両方式とも同程度に順位は低く，劣等グルー プに入っている

以上のように単に残留ヨーク率の点だけから判断する と，同じ合成系に属する溶剤でも非常にすぐれているも のもあれば，かなり劣るものもある，また特に注目され るのは石油系のケロシンであって，グリース分に対する 純粋な溶解能はかなり悪いとみなされるにもかかわら ず，総合的には絞り処理後の成績はかなり良いと考光ら れる。

\section{3 液の疲労性について}

従来の普通洗毛法（せっけんソーダ液や中性洗剤によ る）の場合にも，同一洗液を長く使用していると次第に 洗毛効果が悪くなり，洗い上り羊毛の残脂率が大きく色 沢も劣化することが認められており，これがすなわち洗 液の疲労であって，特に非イオン系洗剂を使用する場合 に著しいとされている。

では溶剂洗毛の場合はどうであろらか，有機溶剤は一 般に油脂分の溶解力は著大であるが，せっけんその他の 洗骫液の呈するような保護コロイド作用が少なく，污れ の粒子を安定に保持けんだくする力は小さいといれれて いる.したがってグリース，スイント，土砂なと゚の不純 物の溶脱が進み液濃度が増加した場合には，洗浄力は急 激に減少し，污れが羊毛瀻維に再付着する傾向すら生じ るといわれる。このようであるとすれば，処理時間の経 過とともに浮遊する污れの量が急激に增加することによ 
り，溶剤の 容脱力の次第に低下することが考えられる が，最適容剂の探求上このような疲学度が溶剂の種類に よってとの程度相違するか, 污れの再付着が発生する限 界濃度はどの程度異なるかなどいいて解析し比較する 必要がある。そしてこの場合，やはり処理方式によって 傾向は異なるものと予想されるのて，浸せき方式と流下 方式の両場合についてそれぞれ則定し検討した。

a. 侵せき方式による場合

実験方法は省略するか，採用溶剂としては前項むての 測定結果から比較上適当なものとして選んた 8 種類によ った，そして抽剂比 $r \alpha_{s}$, 処理後原毛塊の水による抽出 分残留率 $r{ }_{s} R_{s}$, 処理後原毛塊のエーテルによる抽出分 残留率 $r . g R_{s}$ の各項目について則定した。得られた結果

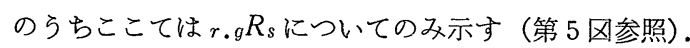

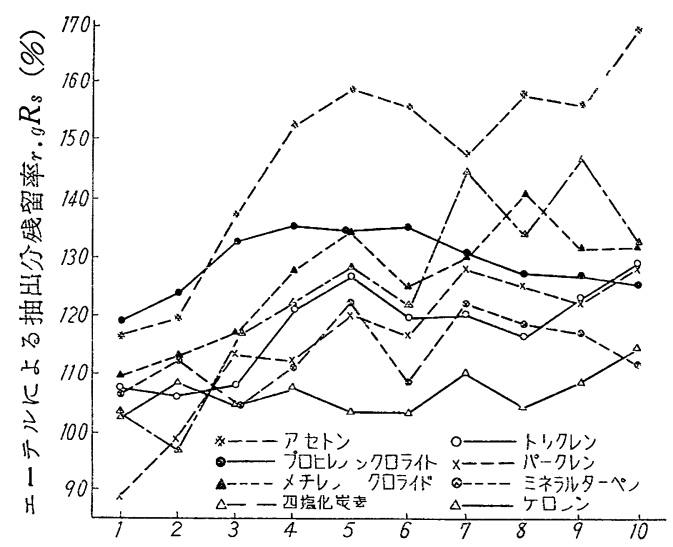

洗毛繰り返乙回数（回）

（第 5 四）浸せき方式による疲労性実験に衫ける 各溶剤の場合の洗毛繰り匣し回数によ る处理後原毛塊のェーテルによる抽出 分残留率 $\left(r_{s} R_{s}\right)$ の变化

な和 $r . s R_{s}$ については全般的に疲労性は認められなく， 浸せき方式による珗毛処理の場合には，との溶剤を使用 しても洗い上り羊毛塊の残留スイント分は，溶剂か新し い場合てもかなり质机ている場合てもほとんと変うらな いことか指摘された。したかって先い上り手毛塊の残留 ヨーク率の変化傾向としては，ここに承まった ${ }_{1.5} R_{s}$ 值 による傾囘と一致し，したかって疲学性のある容剤の場 合には，それは残グリース分の增加のためてあるという ことになるこのような理由から，処理後原毛塊の残留 $\exists ー ク$ 率 $r . y R_{s}$ 值の変化傾向の区示は省略した。第 5 困 によるとヨーク分中のクリース分を主な対象とした場合 の疲労性は容剤の種類によってかなり相違しているよう てある。もっとも疲労性がいと判断されるのはケロシ
ンてあって，1〜10回目委て洗毛を繰り返しても $r . g R_{s}$ 値にはほとんど変化なく（しいてい光は7〜10回てほん の少し大となる程度てある).しかも常に低值を示し，相 当ヨーク分の容解した濁った溶液て洗っても，洗い上りり 羊毛塊の残グリース量をかなり少なくすることが可能な ものと考えられる。ミミラルターペンも同樣な傾向を示 し,やはり疲労性はほとんどないものとみなされる。トリ クレンの場合をみてみると，洗毛繰り返し3回目まては ほとんと差かないか，4回以後沈いては大分残グリ一 ス量は増加している。パークレンの場合はもっと疲労性 が著しく、1 回目処理すなわち新容唷て処理した場合に は残グリース量は非常に少ないか，多数個の試料羊毛塊 を処理していくに従って $r_{. g} R_{s}$ 值はかなりの增大を示 す. 四塩化炭素も同嵄な傾向てあって前者と同程度の疲 労性と判断される.メチレンクロライトの場合るかなり の度労性か認められる。ところか同し合成系としてのプ ロピレンシクロライドの場合はあまり疲労性がないよう $\tau, r . g R_{s}$ 值の变化傾向は中高のカーブを示した. 最後 にアセトンは新しいものても残クリース量か多く容脱力 の悪いことは従来示してきたことと同じてあるか，しか も疲労性も非常に大きく，処理原毛塊の個数がふえ容夜 濃度か増し质れてくるにつれて, 洗い上り羊毛塊の残り゙ リース量は急激に多くなることを示している。

以上の結果を総合的に検討して, 疲労性かないとみな される順に 8 容剤を並べてみるとつきのごとくなる（た たし $r . g R_{s}$ の絶対值の大小は別として).

ケロシン>ミネラルターペン \プロピレンシクロライ

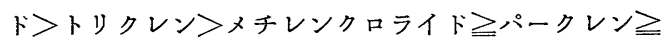
四塩化炭素>アセトン

しかし全般的にみると，処理方式としてて浸せき方式 による場合には，予想外浮疲労性は少ないことが指摘さ れるようて，特にケロシン，ミネラルターペンの石油 系容剂による場合には非常に疲労性か少ないことか注目 される．もっともここて行なった解析は，ヨーク分のみ か村着している試料原毛についててあって，実際処理の ように土砂なとの固形きよう雑物か入ってくると, 疲労 性はもっと大きくなるかもしれない。しかし容剂の種類 による傾向としては，ここに得られた結果と近似するも のと考兄らるる。たより以上適確な考察をするために は，本項之同一試料执よひ同一実験万法によって，せっ けんソータ夜による処理の場合およひ非イオン系の洗剂 液による処理の場合の側定を行ない，その結果と比較す ることか必要てあると考兄られる。 
b. 流下方式による場合

実験方法は省略するか，前項と同し 8 種類の容剤につい $\tau{ }_{r} \alpha_{f},{ }_{1}{ }_{s} R_{f},{ }_{0} R_{f}$ の各項目について測定した。 得 られた結果のうちここては、 $R_{f}$ についてのみ示す（第 6 区参照)。な拉 $r . s R_{f}$ についてはやはり全般的に疲労

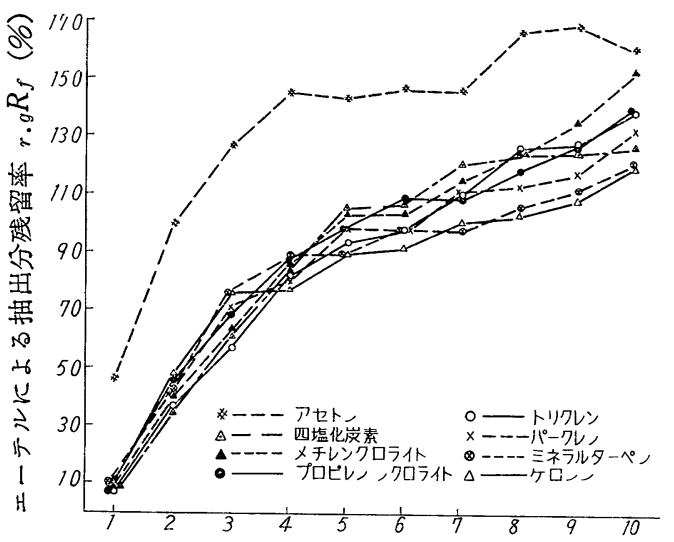

洗毛繰 り 返し回数（回）

（第6区）流下方式による疲労性実験に扎ける各 溶剂の場合の洗毛繰り返し回数による 処理後原毛塊のエーテルによ正抽出分 残留率 $\left({ }_{g} R_{f}\right)$ の変化

性は認められなかった。したかって洗い上り羊毛塊の残 留ヨーク率の変化傾向としては, ここて求まった $r_{.} R_{f}$ 值による傾向と一致する。このような理由からやはり処 理後原毛塊の残留 $\exists$ ーク率 $r{ }_{y} R_{f}$ 值の変化傾向の 冈示 は省略した。第6区によると珗い上り羊毛塊の残留クリ 一ス分については各溶剂の場合とも非常に大きな疲労性 か認められる（全範囲についてみた場合， ${ }_{g} R_{f}$ 值として は，アセトンの場合のみ特別に大きな残留率を示し溶脱 力か劣ることはもちろんてあるか，他の 7 溶剤の場合に はほとんど同榚な值を示し，浸せき方式の場合に比へて 容剤の種類による差はきわめて少ないものとみなすこと かてきる)。そしてとの溶剂においても，侁毛繰り返し の初期段階（1４４回目処理まてあたり）に预いて急激な 疲労性か認められるか，以後は次第にゆるやかとなり， 洗い上り羊毛塊の残留クリース率は一定値に近つく.

以上の結果を総合的に検討してみると，流下方式によ る侁毛処理の場合には，各溶剤の場合ともきわめて著し い疲労性か認められ，合成系溶剮ても石油系溶凨ても同 樣同程度の傾向を示し，容剤の種類による差はない。そ
して前項ても迌へたように, ここて行なった解析はヨー ク分のみか付着している試料原毛についててあって，実 際処理に抢けるように土砂なとの固形きよう雑物か入っ てくると，疲労性はより以上増大するものと考学てよい てあろら。

\section{3.あと がき}

以上の各結果は，基礎的測定としての单一操作による 場合についててあって，残留ヨーク率のかなり多い範囲 における比較てある，実際処理においては珗毛機上りの 最終残脂率は $1 \%$ 以下となっていることか必要てあるの て，このためには多回処理と本格的絞り処理との組合わ せによる実験測定によって実際面に則して処理上り羊毛 塊の残脂率を極小とした場合の結果に基つき考察するこ とか肝要と考兄られ，このような測定解析を別途に行な らことか必要とならう。しかしこの場合ても以上に得ら れた結果とほとんと同一傾向になるものと推察される。

そこて容脱ちについてのつきの解析課題としては，流 下方式の場合のみについて，本報まての結果から選はれ た少数の優秀溶剂について，多回操作（液圧付与の場合 も含めて）和よひ木格的絞り処理によって，残脂率を実 際面に則して $1 \%$ 以下とした場合について詳細に再検討 することてあり，その結果によって容脱力のみについて のより一層適確な最好適溶剂の選択快定か可能となるて あろう。また不容性スイント分の除去を有効に果たすた めの容剂〜水〜界面佸性剂の昆合系の使用についての詳 細な解析検討か必要と考光られる。

さらに総合的な最適容剂を見出すためには，最初に述 べたように，回収性，機械材質への腐蝕性，引火儤発 性, 衛生上, 先い上り羊毛の性状, 結績性, 洒格なとの 各項目について，それそれ政密な実験，検討を実施する ことか必要となる

（什記）本研究は炤和 37 年度に日本羊毛紡㣱会技術 委員会よりの委託研究として実施したものてある.

\section{考文献}

1) 緒学詰, 20, 262 (1964-4)

2) 同 上, 20, 331 (1964-5)

3) 同 上, 20, 485 (1954-7)

4) 同 上, 20, 564, (1964-8) 